\title{
Tingkat literasi keuangan dan kesejahteraan hidup pengusaha batu bata Desa Urek-Urek Kabupaten Malang
}

\author{
Dian Fatma Supriyanti*,Mochamad Dandy Hadi Saputra \\ Universitas Negeri Malang, Jl. Semarang No. 5 Malang, Jawa Timur, Indonesia \\ *Penulis korespondensi, Surel: dianfatma2018@gmail.com
}

Paper received: 3-3-2021; revised: 24-3-2021; accepted: 28-3-2021

\begin{abstract}
Abstrak
Artikel ini bertujuan untuk menganalisis tingkat literasi keuangan pada pengusaha batu bata di Desa Urek-urek Kecamatan Gondanglegi Kabupaten Malang. Metode yang digunakan dalam penelitian ini yaitu metode penelitian kualitatif dengan jenis penelitian fenomenologi. Penelitian ini menggunakan data primer dan data sekunder. Data primer bersumber dari informan utama yang diperoleh melalui wawancara secara langsung dan dari pengusaha batu bata, sedangkan data sekunder diperoleh dari staf kantor Desa Urek-urek serta masyarakat disekitar wilayah usaha batu bata. Teknik pengumpulan data yang digunakan dalam penelitian ini yaitu wawancara dan observasi. Berdasarkan tingkatan literasi keuangan pengusaha batu bata yang berada di Desa Urek-urek Kecamatan Gondanglegi Kabupaten Malang, rata-rata pengusaha batu bata yang ada, sebagian besar tergolong ke dalam tingkatan literasi sedang atau sufficient literate. Literasi keuangan yang dimiliki oleh pengusaha batu bata dapat dikatakan cukup baik, hal ini ditunjukkan dengan pengusaha memilih produk yang berkualitas agar tidak mengalami kerugian baik waktu maupun biaya, memiliki investasi untuk kebutuhan jangka panjang serta dapat menambah pendapatan di kemudian hari. Tingkat literasi keuangan pengusaha batu batu berpengaruh terhadap kesejahteraan hidup dan keberlangsungan usaha yang dijalankan oleh pengusaha batu bata dalam jangka panjang.
\end{abstract}

Kata kunci: tingkat literasi keuangan; pengusaha batu bata

\section{Pendahuluan}

Menghadapi era globalisasi yang diikuti oleh kemajuan teknologi menjadikan kebutuhan akan literasi sangat diperlukan agar dapat mengatasi setiap permasalahan yang terjadi dalam kehidupan sehari-hari. Setiap orang dituntut untuk menghadapi perubahan dengan memiliki pemahaman, kemampuan dan juga wawasan yang baik dalam memenuhi kebutuhan dasar yang semakin kompleks, terutama bagi seseorang yang menjalankan suatu usaha. Permasalahan yang seringkali dihadapi oleh setiap pelaku usaha yaitu mengenai ketidakmampuan dalam mengelola keuangan usaha. Dalam kondisi seperti ini, sangat dibutuhkan pemahaman dan wawasan yang baik terkait literasi keuangan yang berguna dalam pengambilan keputusan maupun pengelolaan keuangan usaha. Pernyataan ini, sejalan dengan (OJK, 2017) yang menjelaskan literasi keuangan sebagai suatu kemampuan yang dimiliki oleh seseorang dalam memahami dan mengelola baik keuangan pribadi maupun keuangan suatu organisasi/usaha agar tidak melakukan kesalahan dalam pengambilan keputusan yang berkaitan dengan keuangan

Penting untuk diketahui, bahwa rendahnya literasi keuangan dapat menyebabkan seseorang mengalami kerugian di masa tua nanti, ketika usia sudah tidak memungkinkan lagi untuk dapat bekerja. Dalam kondisi seperti ini, kebutuhan hidup masih menuntut untuk dipenuhi namun seringkali hal tersebut tidak diiringi dengan kemampuan sumber daya keuangan yang baik, sehingga masa tua yang seharusnya dapat dinikmati bersama anak dan cucu justru dihabiskan dengan mencari pekerjaan untuk mendapatkan penghasilan. Bagi 
seseorang yang bekerja sebagai pegawai pemerintah hal ini tidak menjadi kekhawatiran karena mereka akan mendapat tunjangan hari tua saat masa pensiun tiba, sedangkan seseorang yang bekerja di sektor swasta atau sektor informal, dana pensiun harus sudah disiapkan sejak awal untuk menghindari kerugian di masa tua nanti (Amanita, 2017)

Pemahaman akan literasi keuangan yang rendah akan merugikan seseorang, seperti kesulitan dalam membuat rencana keuangan, kesulitan dalam pengelolaan keuangan, dan kesulitan dalam mengambil keputusan keuangan. Pernyataan ini sejalan dengan (Aribawa, 2016) dimana seseorang yang memiliki pemahaman akan literasi keuangan, akan menghindarkan ia dari setiap permasalahan keuangan. Masalah yang berkaitan dengan keuangan tidak hanya mengenai seseorang yang memiliki pendapatan yang rendah, namun juga disebabkan karena ketidaktahuan dan kesalahan dalam pengaturan terkait keuangan (miss management) misalnya penggunaan kartu kredit yang tidak sesuai prosedur, dan tidak memiliki rancangan pengelolaan keuangan.

Survei Nasional Literasi Keuangan yang dilakukan OJK pada tahun 2013, menunjukkan gambaran kondisi tingkat literasi keuangan yang terjadi di Indonesia. Indeks literasi keuangan masyarakat Indonesia menunjukkan hanya sekitar 21,8\% yang dapat diartikan bahwa dari setiap 100 penduduk hanya sekitar 22 orang yang masuk dalam kategori well literate atau memiliki pemahaman akan literasi keuangan. Survey yang dilakukan pada tahun 2016 menunjukkan adanya peningkatan indeks literasi keuangan masyarakat Indonesia dari 21,8\% menjadi $29,7 \%$.



Gambar 1. Indeks Literasi Keuangan Tahun 2013 dan 2016

Sumber: Otoritas Jasa Keuangan, 2013 dan 2016.

Menurut Otoritas Jasa Keuangan, indeks literasi keuangan terbagi menjadi 4 bagian yaitu: (1) well literate dimana seseorang memiliki pengetahuan dan keyakinan terhadap lembaga jasa keuangan, sehingga dapat menggunakan produk dan jasa dari lembaga keuangan dengan baik; (2) sufficient literate, dimana seseorang memiliki pengetahuan dan keyakinan terhadap lembaga jasa keuangan, namun tidak dapat menggunakan jasa dan produk dari lembaga keuangan dengan baik (3) less literate, dimana seseorang hanya memiliki pengetahuan tentang lembaga jasa keuangan dan produk dan jasa keuangan, tidak memiliki keyakinan/kepercayaan terhadap lembaga jasa keuangan (4) not literate, dimana seseorang tidak memiliki pengetahuan dan keyakinan terhadap lembaga jasa keuangan sehingga tidak 
memiliki keyakinan untuk menggunakan setiap jasa maupun produk yang ditawarkan oleh lembaga jasa keuangan.

Berdasarkan hasil survey di atas dengan jumlah penduduk yang demikian besar, tingkatan tertinggi literasi keuangan masyarakat bukan well literate. Hal tersebut mengindikasikan bahwa sebagian besar masyarakat di Indonesia belum memiliki pengetahuan dan keyakinan terhadap jasa dan lembaga keuangan. Masyarakat Indonesia yang tergolong not literate dalam hal pengelolaan keuangan memiliki persentase yang jauh lebih besar dibandingkan masyarakat yang tergolong well literate dalam hal pengelolaan keuangan. Masyarakat yang tidak memiliki pengetahuan dan pemahaman terkait pengelolaan keuangan yang baik memiliki peluang yang lebih besar dalam menerima risiko dari produk dan jasa keuangan yang digunakannya dikarenakan ketidaktahuan mereka akan adanya risiko dari setiap produk dan jasa keuangan yang ditawarkan oleh lembaga jasa keuangan . Selain itu, masyarakat juga belum mengetahui dan memahami apa sajakah yang termasuk dalam produk dan jasa layanan yang ditawarkan oleh lembaga jasa keuangan.

Penerapan literasi keuangan dalam aktivitas kehidupan sehari-hari sangatlah dibutuhkan oleh setiap masyarakat. Terlebih masyarakat yang memiliki usaha sebagai sumber pemenuhan kebutuhan hidup, dimana para pengusaha semestinya memahami dan menerapkan literasi keuangan dalam menjalankan usahanya. Pengelolaan keuangan yang diterapkan dengan baik, selain menguntungkan pengusaha pribadi, juga memperluas serta mengembangkan usaha yang dijalankan menjadi lebih efektif. Selain itu, ketika seseorang atau pengusaha memiliki kemampuan mengelola keuangan dengan baik, usaha dan lingkungan sekitar berdirinya usaha bisa berkembang lebih baik untuk kedepannya.

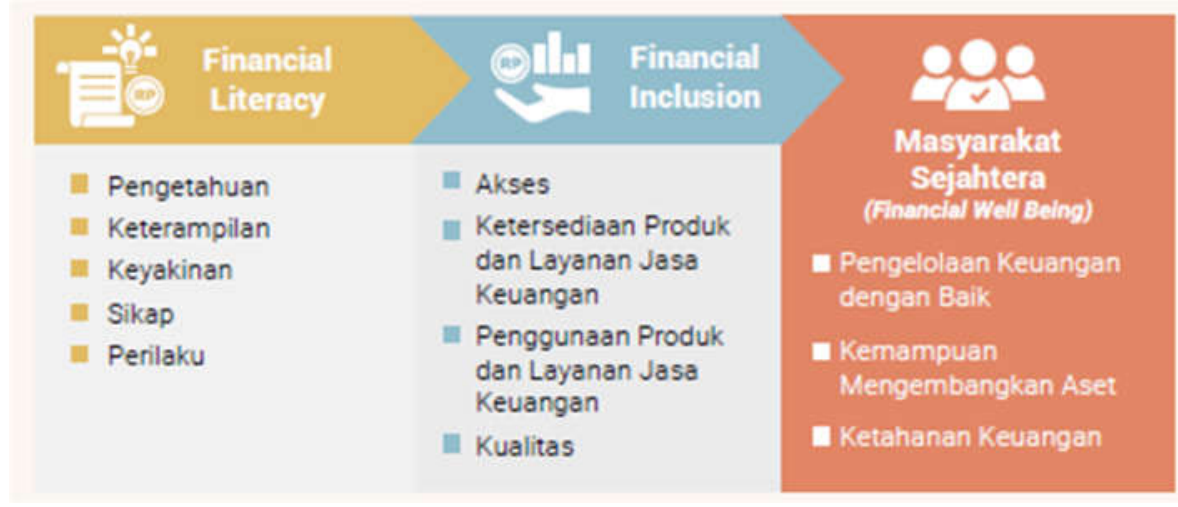

Gambar 2. Konsep Financial Well-Being

Sumber: Strategi Nasional Literasi Keuangan Indonesia (Revisit), 2017

\section{Metode}

Berdasarkan permasalahan yang ada, maka rancangan dalam penelitian ini yaitu menggunakan pendekatan metode kualitatif dengan jenis penelitian fenomenologi. Penentuan jumlah sampel dalam penelitian ini menggunakan teknik purposive random sampling, dimana penulis membuat kriteria untuk menentukan kelayakan informan yang akan di wawancara. Beberapa kriteria persyaratan informan yaitu, (1) pendidikan, (2) pendapatan usaha, (3) usia. 
Data yang digunakan dalam penelitian ini adalah data primer melalui kegiatan wawancara pada informan terpilih dan Data sekunder berasal dari kantor desa setempat berupa data penduduk. Teknik pengumpulan data yang digunakan dalam penelitian ini yaitu teknik wawancara dan observasi. Analisis data yang digunakan meliputi, 1) reduksi data, yaitu data yang masuk maupun hasil data lainnya perlu direduksi sesuai dengan pertanyaanpertanyaan penelitian dan kasus-kasus sesuai dengan fokus penelitian yaitu literasi keuangan pengusaha batu bata. 2) Display data: Berawal dari pemilihan data-data yang telah direduksi terlebih dahulu sesuai dengan kebutuhan dan fokus penelitian ini. Setelah itu diambil data yang terkait dengan literasi keuangan yang mencangkup data berikut: seberapa jauh para pengusaha batu bata mengenal instansi-instansi keuangan yang ada, seberapa besar pemahaman para pengusaha batu bata terhadap literasi keuangan dan produk-produk keuangan, dan bagaimana pola para pengusaha batu bata dalam mengelola keuangan dari usaha yang dijalankan. Display data dilakukan untuk memungkinkan adanya penarikan kesimpulan untuk kebutuhan penelitian kedepannya. 3) Verifikasi data dan kesimpulan: Penarikan kesimpulan pada penelitian ini melalui identifikasi data yang terkait dengan literasi keuangan yang mencangkup data berikut: seberapa jauh para pengusaha batu bata mengenal instansi-instansi keuangan yang ada, seberapa besar pemahaman para pengusaha batu bata terhadap literasi keuangan dan produk-produk keuangan, dan bagaimana pola para pengusaha batu bata dalam mengelola keuangan dari usaha yang dijalankan. Setelah itu peneliti mulai menarik kesimpulan sesuai dengan fokus penelitian yaitu literasi keuangan pengusaha batu bata di Desa Urek-urek, yang sebelumnya telah dikaitkan dengan teori-teori literasi keuangan yang ada.

\section{Hasil dan Pembahasan}

Pembahasan dalam penelitian ini yaitu meliputi (1) Pengusaha batu bata yang tergolong memiliki literasi keuangan Well-Literate, (2) Pengusaha batu bata yang tergolong memiliki literasi keuangan Sufficient-Literate, (3) Pengusaha batu bata yang tergolong memiliki literasi keuangan Less-Literate, dan (4) literasi keuangan pengusaha batu bata dan kesejahteraan hidup.

\subsection{Literasi Keuangan Pengusaha Batu Bata di Desa Urek-urek Kecamatan Gondanglegi Kabupaten Malang}

Berdasarkan pengertian yang mendasari literasi keuangan menurut (OJK, 2017) yang dimaksud dengan literasi keuangan yaitu rangkaian aktivitas yang terdiri dari pengetahuan, keyakinan dan keterampilan dalam mengelola keuangan dengan baik sehingga tidak terjadi kesalahan lagi dalam hal mengelola keuangan. Berdasarkan pengertian tersebut serta menurut hasil penelitian yang telah dilakukan penulis, dapat diketahui terdapat tiga kategori tingkatan literasi keuangan yang dimiliki pengusaha batu bata di desa Urek-urek Kecamatan Gondanglegi Kabupaten Malang, yaitu sebagai berikut:

\subsection{Pengusaha batu bata yang tergolong memiliki literasi keuangan Well- Literate}

Berdasarkan hasil penelitian yang dilakukan diketahui Informan memisahkan antara tabungan keluarga dengan tabungan usaha pada Lembaga perbankan yang berbeda dengan tujuan agar tidak bercampurnya antara kebutuhan keluarga dengan kebutuhan usaha. Kegiatan menabung tersebut merupakan keputusan yang efektif dalam mengelola hasil usaha, 
dimana informan juga menyadari bahwa pekerjaan yang dilakukan tidak memiliki tunjangan pensiun layaknya pegawai negeri sipil, maka dari itu dalam proses menabung tadi informan telah mendaftarkan anak-anaknya dalam tabungan Pendidikan. Tindakan tersebut menggunakan pertimbangan jangka Panjang dan matang, dimana informan memahami dengan betul betapa pentingnya pengetahuan serta Pendidikan bagi keluarga. Hal tersebut juga merupakan strategi yang informan rencanakan guna menghadapi masa pensiun nanti. Hal ini sejalan dengan Hendiks dalam Febriandi (2014) menyatakan bahwa literasi keuangan yang baik dapat digambarkan sebagai kemampuan untuk membuat penilaian informasi dan mengambil tindakan efektif terkait dengan pengelolaan keuangan di masa sekarang dan masa depan yang berkaitan dengan peristiwa kehidupan diantaranya tabungan pensiun, pada saat terjadi pemutusan hubungan kerja (PHK) atau digunakan sebagai biaya pendidikan.

\subsection{Pengusaha batu bata yang tergolong memiliki literasi keuangan Sufficient Literate}

Berdasarkan hasil penelitian yang dilakukan diketahui Pengusaha yang tergolong memiliki literasi keuangan sufficient literate, dalam mengelola keuangan cenderung kepada pemikiran bagaimana penghasilan yang diterima dapat memenuhi kebutuhan keluarga maupun usaha serta dalam usaha peningkatan nilai tambah penghasilan masih bergantung pada situasi dan kondisi yang ada. Pada tingkatan ini, dua dari tiga informan melakukan pencatatan mulai dari perkiraan serta dana usaha yang masuk maupun keluar. Hal tersebut dikarenakan informan menyadari pentingnya pencatatan untuk pengalokasian penghasilan dan ini dilakukan dengan tujuan berjaga-jaga agar tidak terjadi kerugian kedepannya, hal tersebut sejalan dengan (Hidayat, 2020) bahwa faktor terpenting dalam pengalokasian pendapatan adalah perencanaan keuangan. Secara sederhana perencanaan keuangan berkaitan dengan alur masuknya dana dari pendapatan usaha dan alur keluarnya dan untuk konsumsi serta berapa banyak uang yang digunakan untuk menabung dan investasi. sedangkan menurut informan yang tidak melakukan pencatatan secara terperinci dan melakukan penganggaran setelah terbayang atas kebutuhan yang diinginkan. Sedikit berbeda dengan asuransi, informan yang tergolong ke dalam tingkatan ini memiliki pemahaman yang cukup baik akan dasar-dasar investasi. Hal ini terlihat pada rata-rata informan memiliki investasi dalam bentuk tanah.

Selain itu juga beberapa informan memiliki investasi dalam bentuk perhiasan yang disimpan dirumah. Hal tersebut bertujuan selain digunakan untuk memberi tambahan penghasilan dikemudian hari tetapi juga berjaga-jaga dalam menghadapi usia tua. Hal tersebut sejalan dengan pernyataan Budianto dalam (Hidayah, 2018) bahwa motif lain seseorang baik yang bekerja maupun tidak bekerja secara fisik melakukan investasi adalah mereka menyadari akan berhadapan dengan usia pensiun. Rata-rata informan memang belum mampu menjelaskan makna dari investasi yang ada akan tetapi memiliki pemahaman yang cukup mengenai implementasi dalam kehidupan.

\subsection{Pengusaha batu bata yang tergolong memiliki literasi keuangan Less Literate}

Berdasarkan hasil penelitian yang dilakukan diketahui Pengusaha batu bata yang tergolong dalam less literate, cenderung mengkombinasikan pengelolaan serta penggunaan keuangan berdasarkan keinginan pribadi. Perihal pemenuhan kebutuhan informasi tidak selalu merencanakan keuangan yang jelas, hanya sekedar pencatatan-pencatatan kecil dan 
bersifat kebutuhan wajib saja. Terkait penyimpanan dana informan tidak memiliki pertimbangan khusus dalam pengelolaan dananya. Hal tersebut dibuktikan dengan tidak mampunya informan dalam memaksimalkan pelayanan tabungan pada jasa perbankan. Hal ini sejalan dengan pernyataan (Byrne, 2007) yaitu tingkat literasi keuangan yang rendah akan menyebabkan terjadinya kesalahan dalam mengelola dan merencanakan keuangan serta menyebabkan sulit tercapainya kesejahteraan hidup disaat usia tidak produktif lagi. Informan yang tergolong ke dalam tingkatan ini menganggap permasalahan keuangan yang ada baik keuangan usaha maupun keluarga merupakan hal yang wajar dan dapat diselesaikan dengan cara yang mudah tanpa adanya pertimbangan yang cukup, hal tersebut dibuktikan dengan informan yang memilih jalan cepat dalam hal pinjaman yang dilakukan kepada saudara terdekat serta jarang melakukan pencatatan keuangan usaha yang masuk maupun keluar dengan alasan agar pekerjaan tidak menjadi ribet atau sulit.

Berbeda dengan informan yang tergolong kedalam tingkatan well literate dimana perbandingan dapat dilihat dari segi usia, Pendidikan, dan pendapatan usaha. Informan yang tergolong less literate memiliki usia yang lebih tua dibandingkan dengan informan well literate. Begitu pula dari sisi Pendidikan informan pada tingkatan ini hanya menempuh Pendidikan hingga SMP serta pendapatan yang dihasilkan dari usaha yang dijalankan juga mengalami perbedaan dengan informan well literate. Dapat diketahui bahwa adanya hubungan yang sejalan antara usia, Pendidikan, dan pendapatan terhadap tingkatan literasi yang dimiliki oleh pengusaha. Hal ini sejalan dengan pernyataan (Sofiana, 2016) literasi keuangan dapat dilihat berdasarkan umur, pendidikan dan tingkat pengeluaran. Dimana pola hubungan literasi keuangan dengan umur menunjukkan mempunyai hubungan positif dimana semakin tua seseorang maka semakin rendah literasi keuangannya, hal ini dikarenakan produk-produk lembaga keuangan dan jasa keuangan di Indonesia belum berkembang seperti saat ini.

Kemudian pola hubungan antara tingkat Pendidikan dengan tingkat literasi keuangan. Penelitian ini memperkuat kesimpulan bahwa tingkat Pendidikan mempunyai pola hubungan positif. Semakin tinggi Pendidikan, maka tingkat literasi keuangan informan juga semakin tinggi, dan yang terakhir pola hubungan positif antara tingkat pengeluaran dengan tingkat literasi keuangan, pola hubungan tersebut dijelaskan dengan semakin tinggi strata sosial masyarakat maka semakin tinggi pula tingkat literasinya

\subsection{Literasi Keuangan Pengusaha Batu Bata dan Kesejahteraan Hidup}

Berdasarkan hasil penelitian diketahui tingkat literasi keuangan juga memiliki keterkaitan sejalan terhadap kesejahteraan hidup, dimana seseorang yang memiliki tingkat literasi keuangan tinggi maka kesejahteraan hidup yang dimiliki juga akan semakin besar, dikarenakan telah mampu mengelola serta menerapkan keuangan dalam menjalankan usaha dengan benar dan begitu juga sebaliknya. Hal ini sejalan dengan pernyataan Sina (2012) dalam Silvy (2013) bahwa rendahnya tingkat literasi keuangan berdampak pada kesejahteraan hidup. Dimana seseorang membutuhkan literasi keuangan untuk dapat meningkatkan kesejahteraan hidup. Selain itu, memiliki tingkat literasi keuangan yang tinggi akan berpengaruh terhadap pemasukan usaha, karena informan akan menjalankan usahanya dengan lebih bijak. 
Selain itu juga dengan literasi keuangan yang baik pengusaha mampu mengembangkan usaha yang dijalankan memiliki prospek yang baik kedepannya sehingga output yang dihasilkan semakin meningkat. Secara tidak langsung dengan adanya peningkatan produksi, para pengusaha juga turut serta menambah penghasilan bagi masyarakat sekitar, dimana masyarakat sekitar daerah usaha ikut bekerja sebagai tenaga kerja harian. Selain itu juga dengan adanya literasi keuangan yang baik berdampak pada infrastruktur desa seperti pembuatan gapura jalan adanya renovasi musholla setempat sebagai bentuk tanggung jawab sosial yang dilakukan pengusaha batu bata di desa Urek-urek Kecamatan Gondanglegi Kabupaten Malang.

\subsection{Temuan Penelitian}

Hasil penelitian ini menunjukkan bahwa (1) Mengenai kategori usia dapat diketahui bahwa informan yang tergolong well-literate memiliki usia yang lebih muda dibandingkan dengan informan yang tergolong less-literate, dimana semakin muda usia informan semakin besar tingkat literasi, (2) Mengenai kategori Pendidikan dapat diketahui bahwa informan yang tergolong well-literate dan sufficient-literate menempuh Pendidikan hingga jenjang SMA, sedangkan informan yang tergolong less-literate menempuh Pendidikan hingga jenjang SMP, sehingga dapat diketahui bahwa semakin tinggi jenjang Pendidikan semakin besar tingkat literasi keuangannya, (3) Mengenai kategori pendapatan usaha dapat diketahui bahwa informan yang memiliki rata-rata pendapatan usaha yang lebih besar tergolong kedalam wellliterate sedangkan informan yang memiliki rata-rata pendapatan usaha yang lebih rendah tergolong kedalam sufficient-literate dan less-literate, (4) Dimana secara tidak langsung dengan adanya usaha batu bata, berdampak kepada kesejahteraan bagi masyarakat di lingkungan sekitar tempat usaha.

\section{Simpulan}

Berdasarkan hasil penelitian ini dapat ditarik kesimpulan bahwa: (1) rata-rata pengusaha batu bata yang ada, lebih banyak tergolong kedalam tingkatan literasi keuangan sedang atau sufficient-literate, dimana dari 5 (lima) informan yang dipilih berdasarkan kriteria yang telah ditetapkan oleh penulis; (2) Pengusaha batu bata yang ada masih memiliki pandangan bahwa Lembaga Keuangan hanya memiliki layanan jasa simpan dan pinjam serta masih terdapat sedikit informan yang memiliki kepercayaan terhadap Lembaga Keuangan; (3) Literasi keuangan yang dimiliki oleh pengusaha batu bata dapat dikatakan cukup baik, hal ini ditunjukan dengan pengusaha yang lebih memilih produk yang lebih berkualitas agar tidak terjadinya kerugian baik waktu maupun biaya; memiliki investasi untuk kebutuhan jangka Panjang serta dapat menambah pendapatan di kemudian hari; memiliki pertimbangan terhadap kewajiban serta pemenuhan usaha maupun keluarga dan adanya kesadaran sosial dalam melihat keadaan sekitar dengan mengajak masyarakat sekitar sebagai pekerja guna menambah penghasilan mereka. Selain pengaruh kesejahteraan yang diterima masyarakat sekitar, tingkat literasi keuangan pengusaha batu bata berdampak kepada kesejahteraan dirinya sendiri serta keberlangsungan usaha yang dijalankan dalam jangka Panjang.

\section{Daftar Rujukan}

Aribawa, D. (2016). Pengaruh literasi keuangan terhadap kinerja dan keberlangsungan umkm di jawa tengah. Journal Siasat Bisnis, 20(1), 1-13. https://doi.org/10.1007/s10006-013-0431-4

Byrne, a. (2007). Employee saving and investment decisions in defined contribution pension plans: Survey Evidence from the UK. FInancial Services Review, 16, 19-40. http://strathprints.strath.ac.uk/8167/ 
Jurnal Ekonomi, Bisnis dan Pendidikan, 1(3), 2021, 232-239

Hidayah, N. (2018). Alokasi Pendapatan Dan Literasi Keuangan Studi Kasus pada Desa Sidomukti Kecamatan Plaosan Kabupaten Magetan. Keberlanjutan: Jurnal Manajemen dan Jurnal Akuntansi, 3(1) 827-856.

Hidayat, S. (2020). Literasi Keuangan Untuk Pengelolaan Keuangan Pribadi. Syariah (EKUITAS), 1(2), 130-133. https://slideplayer.info/slide/1972619/

OJK. (2017). Strategi Nasional Literasi Keuangan Indonesia (Revisit 2017). Otoritas Jasa Keuangan, 1-99.

Sofiana, D. (2016). Persepsi Pengusaha Industri Sanitair Terkait Tingkat Literasi Keuangan. Jurnal Ekonomi Dan Ekonomi Studi Pembangunan, 8(1), 33-39. https://doi.org/10.17977/um002v8i12016p033

Yushita, A. N. (2017). Pentingnya literasi keuangan bagi pengelolaan keuangan pribadi. Nominal: Barometer Riset Akuntansi dan Manajemen, 6(1), 11-26. 